\title{
Od czego zależy jakość dialogu społecznego? Koncepcja modelu państwa administracyjnego i państwa sieciowego na przykładzie instytucji dialogu społecznego
}

DOI: $10.35757 / C I V .2007 .10 .07$

Od czego zależy jakość dialogu społecznego w krajach Europy Środkowo-Wschodniej? Państwa naszego regionu mają wspólne dziedzictwo okresu socjalistycznego. Łącza je także trudne doświadczenia transformacji gospodarczej i politycznej. Od niedawna jesteśmy również członkami Unii Europejskiej. Jak się wydaje, wszystkie trzy wyżej wymienione uwarunkowania wpływaja na jakość dialogu społecznego, tj. konsultacji społecznych dotyczących problematyki relacji między pracodawcami i pracownikami. Do tego należy dodać uwarunkowania globalizującej się gospodarki oraz - połączone $z$ integracja europejska - wyzwania konkurencyjności na wspólnym rynku. Właśnie te ostatnie uwarunkowania zdaja się najbardziej utrudniać dialog społeczny. Powodują, że jest on $\mathrm{w}$ znacznym stopniu instrumentem poprawiania konkurencyjności krajowej gospodarki i liberalizowania przepisów regulujących 
wzajemne relacje między pracodawcami i pracownikami ${ }^{1}$. Takie założenia dla funkcjonowania omawianych instytucji stawiaja związki zawodowe $\mathrm{w}$ trudnej sytuacji. W oczywisty sposób utrudnia to budowanie solidnych instytucji dialogu społecznego w nowych krajach członkowskich.

\section{Instytucje dialogu społecznego w krajach Europy Środkowo-Wschodniej}

Szczególna forma negocjacji społecznych analizowana w niniejszym opracowaniu sa instytucje trójstronne w trzech krajach naszego regionu: Polsce, Litwie i Estonii ${ }^{2}$. Sa to instytucje skupiające oprócz organizacji pracowników i pracodawców także przedstawicieli państwa, którzy najczęściej sa wprowadzani na szczeblu centralnym (krajowym). Instytucje dialogu społecznego w krajach Europy Środkowo-Wschodniej, choć stosunkowo liczne i funkcjonujace przy wielu instytucjach państwowych, sa generalnie słabe ${ }^{3}$. Na przykład w Polsce przy urzędach centralnych istnieje około 100

\footnotetext{
1 R. Boyer: The Unanticipated Fallout of European Monetary Union: The Political and Institutional Deficits of the Euro, w: C. Crouch (red.): After the Euro: Shaping Institutions for Governance in the Wake of the European Monetary Union, Oxford University Press, Oxford 2000; J.E. Dølvik: Industrial Relations in EMU: Are Renationalization and Europeanization Two Sides of the Same Coin?, w: A. Martin, G. Ross: Euros and Europeans. Monetary Integration and the European Model of Society, Cambridge University Press, Cambridge 2005.

2 Niniejszy tekst zawiera podsumowanie badań przeprowadzonych przez Instytut Spraw Publicznych w latach 2004-2005. M. Fałkowski, T.G. Grosse, O Napiontek: Dialog społeczny i obywatelski $w$ Polsce 2002-2005, Instytut Spraw Publicznych, Warszawa 2006. Szerzej na ten temat założeń i celów projektu por. T.G. Grosse: Democratization, Capture of the State and New Forms of Governance in CEE Countries, Inception Report, 2005. Raporty $z$ badan krajowych: M. Fałkowski: Tripartite Commission, Effectiveness, Legitimacy and Pathologies of Weak State. Case Study Report Poland, 2005; R. Stafejeva: Tripartite Commission, Effectiveness, Legitimacy and Pathologies of Weak State, Case Study Report Lithuania, 2005; E. Sootla, T.G. Grosse (2005): Tripartite Commission, Effectiveness, Legitimacy and Pathologies of Weak State, Case Study Report Estonia, 2005; Podsumowanie wyników projektu badawczego: T.G. Grosse: New Modes of Governance in New Member Countries, 2006 (http://www.eu-newgov.org/datalists/ documents.asp).

3 Podobny wniosek w innych badaniach: M. Mailand, J. Due: Social Dialogue in Central and Eastern Europe: Present State and Future Development, „European Journal of Industrial Relations" 2004, vol. 10, nr 2, s. 179-197.
} 
instytucji konsultacyjnych ${ }^{4}$, jednak ich praktyczne znaczenie (poza wyjatkami) jest niewielkie. We wszystkich trzech badanych krajach duża część tych instytucji ma charakter czysto formalny, na przykład zwiazany $z$ zobowiazaniami wobec Międzynarodowej Organizacji Pracy. Wiele instytucji realizuje jedynie działania rutynowe, nie związane $z$ podejmowaniem żadnych wiążacych decyzji ani prowadzeniem systematycznej i pogłębionej debaty społecznej.

Poziom formalizacji krajowych instytucji trójstronnych jest zróżnicowany. W Polsce $i$ na Litwie sa to instytucje stałe, $z$ długoletnim doświadczeniem. Rada Trójstronna na Litwie funkcjonuje w sposób ciagły. Natomiast polska Komisja Trójstronna, choć ma najdłuższy staż (powstała w roku 1994), ze względów politycznych okresowo zaprzestaje działalności. Jednocześnie wydaje się znacznie mniej efektywna pod względem możliwości osiagania porozumień niż litewska Rada Trójstronna. W Estonii w zasadzie nie ma stałej instytucji trójstronnej ${ }^{5}$. Negocjacje między stronami sa prowadzone ad hoc, na prośbę którejś ze stron, poza istniejacymi strukturami konsultacyjnymi. Mamy więc tutaj do czynienia raczej $z$ cyklicznymi negocjacjami trójstronnymi organizowanymi wokół poszczególnych spraw publicznych niż $z$ trwała instytucja dialogu społecznego.

Słabość instytucji trójstronnych w trzech badanych krajach wynika przede wszystkim $z$ wadliwej lub niewystarczajacej regulacji. Nie zapewnia ona systematyczności funkcjonowania dialogu. $\mathrm{Na}$ przykład w Estonii przystapienie do konsultacji ma charakter dobrowolny oraz zależy wyłącznie od dobrej woli rządu i partnerów społecznych. Stwarzało to niekiedy możliwości rządowi lub organizacjom pracodawców zablokowania rozmów inicjowanych przez zwiąki zawodowe ${ }^{6}$. Przepisy nie gwarantuja także przedkładania przez rząd na forum tych instytucji wszystkich projektów legis-

\footnotetext{
4 D. Długosz, J.J. Wygnański: Obywatele współdecydują. Przewodnik po partycypacji społecznej, Stowarzyszenie na rzecz Forum Inicjatyw Pozarzadowych, Warszawa 2005.

5 Nie licząc Rady Społeczno-Ekonomicznej (Social and Economic Council), która nie ma żadnego realnego wpływu na proces legislacyjny.

6 E. Sootla, T.G. Grosse: Tripartite... .
} 
lacyjnych $z$ zakresu stosunków przemysłowych ${ }^{7}$ lub spraw społecznych. Dlatego we wszystkich badanych krajach była widoczna praktyka omijania procesu konsultacji społecznych, nawet wtedy, kiedy administracja była ustawowo zobligowana do takich konsultacji: w Polsce i na Litwie. Przepisy sa formułowane w sposób mało precyzyjny, co zwiększa możliwości interpretacyjne dla najsilniejszej strony, jaka sa przedstawiciele rządu. Jednocześnie charakter porozumień nie ma formalnego znaczenia decyzyjnego, ale jedynie doradczo-konsultacyjny. Brakuje mechanizmów egzekwujacych ustalenia zawarte $\mathrm{w}$ instytucjach trójstronnych, a także mechanizmów monitorujących ich wdrażanie. W widoczny sposób obniża to wiarygodność rządu i instytucji dialogu dla partnerów społecznych. Warto jednak zauważyć, że porozumienia wypracowane $\mathrm{w}$ dialogu trójstronnym, dotyczace projektów legislacyjnych, były zazwyczaj łatwiej przyjmowane w narodowych parlamentach.

Słabość dialogu trójstronnego w krajach Europy Środkowo-Wschodniej wynika także ze słabości wewnętrznej rządu i partnerów społecznych. W przypadku rzadu jest to zwiazane przede wszystkim $z$ brakiem koordynacji między poszczególnymi ministrami. W niektórych przypadkach instytucje trójstronne były widownia rywalizacji między ministrami lub wzajemnego rozgrywania wpływów wśród partnerów społecznych przeciwko innym przedstawicielom rządu. Szczególnym przejawem słabości rządu jest występowanie kompleksu powiąań branżowych, oznaczających zespolenie interesów między działaczami związkowymi, przedstawicielami pracodawców lub zarządów przedsiębiorstw państwowych, politykami i urzędnikami ściśle powiązanymi $z$ interesami danych branż. W przypadku tradycyjnie silnych sektorów (na przykład związanych z przemysłem ciężkim) takie kompleksy interesów potrafiły blokować zarówno politykę całego rząu, jak i możliwość porozumienia na forum instytucji trójstronnej (zwłaszcza wtedy, kiedy ustalenia trójstronne naruszały dotychczasowe przywileje danej branży).

7 Stosunki przemysłowe (industrial relations) dotycza relacji między pracownikami a pracodawcami. 
W przypadku partnerów społecznych we wszystkich krajach notowany jest niski, a nawet malejacy poziom ich społecznej reprezentatywności. Liczba członków zwiazków zawodowych od lat systematycznie spada ${ }^{8}$. O słabości organizacji społecznych decyduje również brak wystarczających środków finansowych lub pomocy eksperckiej oraz niedostateczne doświadczenie działaczy. Istotnym czynnikiem wpływającym na słabość omawianych organizacji jest ich wewnętrzne rozbicie, rywalizacja o członków lub wpływy polityczne oraz brak skłonności do prezentowania wspólnego stanowiska ponad podziałami. Jako przykład słabości organizacji pracowniczych $\mathrm{w}$ Estonii może posłużyć panująca w tym kraju opinia na temat działaczy zwiazkowych. Sa oni postrzegani jako spadkobiercy organizacji $z$ czasów socjalistycznych, zdominowanych przez wpływy partii i ideologii komunistycznej ${ }^{9}$. Zupełnie inny jest autorytet związkow zawodowych w Polsce. Związek „Solidarność" jest spadkobierca ruchu opozycyjnego przeciwko państwu socjalistycznemu, choć prestiż tego zwiazku podupadł wraz z uwikłaniem w bieżąca politykę i aktywne poparcie prawicowego rządu w latach 1997-2001.

Interesująca kwestią dotycząca dialogu społecznego $\mathrm{w}$ okresie transformacji jest prześledzenie dynamiki zmiany wzajemnych relacji i siły negocjacyjnej poszczególnych stron dialogu. W początkowym okresie transformacji systemowej w Polsce zwiąki zawodowe miały stosunkowo silna pozycję polityczna oraz potencjalnie duży wpływ na decyzje dotyczące kształtowania ustroju gospodarczego i stosunków przemysłowych. Wynikało to $z$ faktu upadku realnego socjalizmu, który to upadek został $\mathrm{w}$ dużym stopniu wywołany przez związek zawodowy „Solidarność” i powiązanych z nim polityków opozycyjnych. Później duża część tych polityków wywierała ogromny wpływ na decyzje rządu i kierunki procesu transformacji ustrojowej. Wraz $z$ upływem czasu słabła pozycja polityczna związków zawodowych, zwłaszcza po nieudanej próbie wspomnia-

\footnotetext{
Por. Industrial Relations in Europe 2004, European Commission, Brussels 2004, s. 19.
}

E. Sootla, T.G. Grosse: Tripartite... . 
nego już bliskiego współdziałania między ugrupowaniem rządowym (Akcja Wyborcza „Solidarność) a zwiąkiem zawodowym „Solidarność". Natomiast wpływ organizacji biznesu na kształtowanie stosunków przemysłowych $\mathrm{w}$ badanych krajach systematycznie zyskiwał na znaczeniu. Jest to zwiazane $z$ szeregiem czynników, m.in. wzrastająca rola koncernów transnarodowych $\mathrm{w}$ gospodarkach tych krajów. Było to także spowodowane przez coraz szybsza prywatyzację (lub likwidację) przedsiębiorstw państwowych, które były naturalnym siedliskiem zwiąków zawodowych. Pozycję negocjacyjna zwiazków zawodowych osłabia ponadto wysokie bezrobocie strukturalne, a także liberalny kierunek zmian systemowych wprowadzonych po roku 1989, zwłaszcza w Estonii i w Polsce.

Organizacje społeczne w różny sposób dażą do wzmocnienia własnej pozycji w dialogu trójstronnym. Uczestnictwo w tym dialogu stwarza im przede wszystkim możliwość poprawienia wizerunku. Ponadto dążą do tworzenia szerszych konfederacji związkowych lub przeciwnie - ostro rywalizują o pracowników $z$ konkurencyjnymi centralami zwiazkowymi. Przykładem nietypowej tendencji konsolidacyjnej jest Estonian Association of Employers and Industry, które grupuje zarówno przedsiębiorców, jak i organizacje pracownicze. Jak się wydaje, może to mieć związek $z$ niskim autorytetem związków zawodowych w Estonii, wynikającym $z$ tradycji socjalistycznej, a także $z$ próbą zwiększenia szans realizowania interesów związkowych wspólnie $z$ organizacjami biznesu. Związki zawodowe na Litwie zwiększaja swoja siłe i wpływ na polityke publiczna poprzez dużą aktywność na forum Rady Trójstronnej, a także intensywnie wykorzystując pomoc ekspertów $z$ krajów skandynawskich.

Innym sposobem nadrobienia słabości organizacji społecznych sa próby bezpośrednich kontaktów $z$ rządem lub partiami politycznymi. Organizacje biznesu coraz częściej nawiązują bliski kontakt $z$ politykami i urzędnikami piastujaccymi wysokie funkcje państwowe. Silny wpływ na decydentów - zwłaszcza nieformalny - maja w Estonii i w Polsce. Udział organizacji biznesu w pracach 
polskiej Komisji Trójstronnej wydaje się związany właśnie $z$ chęcią większego dostępu do polityków i informacji o pracach rządu, $z$ próbą wzmocnienia wizerunku publicznego danej organizacji, a także $z$ możliwościa zablokowania niekorzystnej dla pracodawców regulacji ustawowej na forum Komisji ${ }^{10}$.

\section{Efektywność dialogu społecznego}

Słabość instytucji dialogu wpływa na ich ogólnie niską efektywność, zwłaszcza w odniesieniu do zawieranych porozumień między stronami ${ }^{11}$. Między krajami naszego regionu istnieja jednak duże różnice pod tym względem. Najskuteczniejszą instytucją wydaje się litewska Rada Trójstronna. Jest to powiazane $z$ istotnymi czynnikami kulturowymi i instytucjonalnymi. Zwiazki zawodowe na Litwie, mimo różnych sympatii i afiliacji politycznych oraz rywalizacji o członków, potrafią się zdobyć na uzgadnianie stanowisk przed posiedzeniami Rady. Organizacje pracowników reprezentowane $\mathrm{w}$ instytucji trójstronnej podpisały porozumienie o konsultacji wspólnego stanowiska, a także o niezgłaszaniu wzajemnie opozycyjnych wniosków na forum Rady. Podobne memorandum podpisały również organizacje pracodawców. Wypracowaniu kompromisu służy także regulamin organizacyjny Rady. Przedstawiciele pracodawców i pracowników sa zobowiąani do konsultowania swoich stanowisk przed spotkaniami Rady. Propozycje dokumentów powinny być przesyłane przynajmniej $z$ dziesięciodniowym wyprzedzeniem, a program posiedzenia jest uzgadniany $z$ partnerami społecznymi odpowiednio wcześniej. Porozumienie uznaje się za zawarte w sytuacji zgody wszystkich trzech stron, ale nie-

\footnotetext{
${ }^{10}$ M. Fałkowski: Tripartite...

${ }^{11}$ W każdym $z$ trzech krajów przeanalizowano dwa wybrane przykłady debat prowadzonych w latach 2001-2005. Wyróżniały się one pod względem zainteresowania społecznego i były powiązane $z$ reformami systemowymi. Dotyczyły między innymi zmian w kodeksach pracy, wprowadzenia płacy minimalnej, reformy finansów publicznych w zakresie systemów zabezpieczenia społecznego itp.
} 
koniecznie wszystkich reprezentowanych organizacji ${ }^{12}$. Odmienna sytuacja jest w Polsce, gdzie wystarczy brak zgody jednej $z$ siedmiu organizacji społecznych, aby zablokować całe porozumienie. Jest to więc regulacja znacząco obniżająca możliwości efektywnego działania Komisji Trójstronnej.

Innymi czynnikami podwyższającymi skuteczność pracy Rady Trójstronnej na Litwie są dobrze rozwinięty system komunikacji wewnątrz organizacji społecznych oraz zwyczaj szerokich konsultacji $z$ członkami organizacji przed posiedzeniami Rady. Skuteczności sprzyja także duże doświadczenie działaczy społecznych oraz wysoka aktywność związków na forum Rady. Ważnym elementem presji przedstawicieli pracowników jest nagłaśnianie własnych postulatów w mediach oraz akcje informacyjne prowadzone wśród polityków (pikiety, wysyłka broszur informacyjnych itp.). Związkowcy wykorzystuja również kontakty $\mathrm{z}$ politykami $\mathrm{w}$ parlamencie i rządzie dla wspólnych celów strony pracowniczej. W ten sposób „wychodza” poza ramy instytucji trójstronnej i szukaja maksymalnie szerokiego poparcia dla swoich postulatów. W tych działaniach odznaczaja się znacznie większą aktywnościa niż przedstawiciele organizacji biznesu.

Kształt instytucji organizujących prace dialogu społecznego ma zatem bezpośredni wpływ na efektywność zawieranych porozumień. Niektóre rozwiązania ukierunkowuja rozmowy na forum instytucji trójstronnej $\mathrm{w}$ stronę poszukiwania porozumienia. Przykładowym rozwiazaniem sa silne kompetencje koordynujace sekretariatu Rady Trójstronnej na Litwie, który nie tylko pośredniczy $\mathrm{w}$ podejmowaniu wstępnych decyzji dotyczacych procedowania w Radzie, ale także jest odpowiedzialny za przekazywanie informacji między rządem a partnerami społecznymi. Organizacje społeczne nie moga występować o dokumenty potrzebne do pracy w Radzie bezpośrednio do poszczególnych ministrów ${ }^{13}$.

${ }^{12}$ Por. R. Stafejeva: Tripartite...

13 Ibidem. 
Instytucje trójstronne moga również utrudniać zawieranie porozumień i „wypychać” partnerów społecznych poza swe struktury. Nieefektywność funkcjonowania dialogu trójstronnego sprzyja bowiem poszukiwaniu innych możliwości wpływu na władze, najczęściej nieformalnego. Może to być związane $z$ upartyjnieniem organizacji społecznych, szukaniem bezpośredniego dostępu do decydentów rządowych itd. Przykłady tego typu zjawisk występuja zarówno w Polsce, jak i w Estonii, gdzie struktury dialogu trójstronnego sa relatywnie najsłabsze.

Słabość instytucji dialogu powoduje także wejście w mechanizm błędnego koła osłabiania dialogu społecznego. Zamiast poszukiwania rozwiązań korygujących i wzmacniajacych instytucje trójstronne, decydenci starają się omijać te instytucje, poszukując porozumienia $z$ partnerami społecznymi poza instytucjami trójstronnymi lub kreując inne areny dialogu, bardziej funkcjonalne $z$ punktu widzenia interesów decydentów. Jako przykład może posłużyć Polska, gdzie jedyne porozumienie między partnerami społecznymi i rządem w ostatnich latach, prowadzace do zmian ustawowych w parlamencie było zawarte poza strukturami Komisji Trójstronnej (porozumienie $z$ roku 2002 w sprawie Kodeksu pracy). Jednocześnie w sytuacji, kiedy przedstawiciele rządu uznali, że Komisja nie spełnia ich oczekiwań, odwołano się do zupełnie nowych i doraźnych mechanizmów dialogu obywatelskiego ${ }^{14}$. Opisywane działania sprzyjają marginalizacji instytucji trójstronnych, okresowemu „zawieszaniu” aktywności tych instytucji, a także ograniczeniu ich funkcjonowania do czynności rutynowych, bez realnego wpływu na decyzje systemowe.

$\mathrm{Z}$ punktu widzenia decydentów państwowych udział $\mathrm{w}$ dialogu społecznym jest związany $z$ kwestia wyboru między demokratyzacją (uspołecznieniem) a efektywnością polityk publicznych ${ }^{15}$. Spro-

\footnotetext{
${ }_{14}$ M. Fałkowski, T.G. Grosse, O. Napiontek: Dialog...

${ }_{15} \mathrm{O}$ dylemacie wyboru między skutecznościa a popularnościa polityk i instytucji politycznych pisało wielu autorów. Por. szerzej m.in.: R.A. Dahl: A Democratic Dilemma: System Effectiveness versus Citizen Participation, „Political Science Quarterly” 1994, nr 109 (1); B. Barry: Is Democracy Special? Democracy and Power, Oxford University Press, Oxford 1991, s. 24-60; Ch.R. Beitz: Political Equality, Princeton University Press, Princeton, N.J. 1989.
} 
wadza się głównie do tego, czy polityki należy realizować w sposób dyskrecjonalny, ale skuteczny, czy też konsultować je społecznie i narazić się na ryzyko spowolnienia procesu decyzyjnego, utrudnienia podejmowania decyzji niepopularnych lub trudności podjęcia decyzji ze względu na sprzeczności interesów między partnerami społecznymi. W działalności instytucji trójstronnych widoczny jest więc dylemat decydentów między efektywnością realizowania polityk publicznych a dialogiem trójstronnym. Rozpoczęcie konsultacji, zwłaszcza w kwestiach społecznie drażliwych, wiązało się $z$ ryzykiem spowolnienia procesów legislacyjnych lub poważna zmiana propozycji rządowych. Dodatkowo, w sytuacji ostrej konfrontacji między propozycjami administracji a stanowiskiem partnerów społecznych (lub upolitycznienia dialogu) mogło to prowadzić do zablokowania polityki rządu. Wiązało się także z możliwością osłabienia jego autorytetu społecznego, zwłaszcza $\mathrm{w}$ przypadku forsowania rozwiązan oprotestowanych przez partnerów społecznych i nagłośnienia konfliktu w mediach.

Instytucje dialogu współtworzą również zwyczaje i nieformalne normy tego dialogu. Na przykład wymóg konsultacji między partnerami społecznymi na Litwie przed posiedzeniami Rady Trójstronnej zwiększa liczbę wzajemnych spotkań (również kontaktów nieformalnych między działaczami społecznymi), a także wpływa na rozwój kultury współdziałania. Instytucje utrudniajace zawarcie porozumienia wpływaja natomiast na podkreślanie odrębności własnego stanowiska przez poszczególne organizacje. Skłaniaja je do manifestacyjnego blokowania porozumienia, nie zaś do szukania kompromisu. Jest to bardziej racjonalne dla wizerunku społecznego organizacji niż dążenie do porozumienia, które trudno osiagnąć.

\section{Tradycja socjalistyczna dialogu}

W krajach Europy Środkowo-Wschodniej istnieje zupełnie odmienna niż na zachodzie kontynentu tradycja państwa, kultura 
organizacyjna administracji i kultura polityczna ${ }^{16}$. Jest to związane $\mathrm{z}$ brakiem demokracji w okresie państwa socjalistycznego (w latach 1945-1989) oraz silna dominacja polityczna ZSRR nad krajami tego regionu. W rezultacie struktury państwa funkcjonowały w ramach modelu silnie scentralizowanego, którego ważna cechą była kontrola partii komunistycznej nad administracja i przeniesienie do niej reguł zarzadzania charakterystycznych dla instytucji wojskowych ${ }^{17}$. Specyfika "dialogu społecznego" w tym ustroju politycznym polegała na ograniczeniu niezależnej od państwa aktywności społeczeństwa oraz instrumentalnym podporząkowaniu tego dialogu celom politycznym i ideologicznym państwa komunistycznego.

Analizujac cechy instytucji „dialogu społecznego” w okresie realnego socjalizmu, można wymienić następujące elementy charakterystyczne:

- Ogólna słabość instytucji dialogu społecznego. Zgodnie z szersza tradycja państwa socjalistycznego dialog opierał się na arbitralnych decyzja politycznych, a nie na normach prawnych lub trwałych rozwiazaniach instytucjonalnych. Było to zwiazane ze stosunkowo niskim autorytetem procedur i słabościa instytucji formalnych w porównaniu ze znaczeniem arbitralnych decyzji politycznych i autorytetu personalnego decydentów ${ }^{18}$. W sytuacji słabości instytucji skuteczność działań politycznych w dużym stopniu opierała się na cechach osobistych lidera organizacji i jego pozycji politycznej w układzie władzy. W przypadku słabego lidera rola danej struktury administracyjnej najczęściej ulegała marginalizacji.

\footnotetext{
${ }^{16}$ Por. definicje kultury politycznej: P. Sztompka: Socjologia: analiza społeczeństwa, Wydawnictwo Znak, Kraków 2002. Zastosowanie tego terminu w naukach społecznych: W. Markiewicz: Kultura polityczna, jako przedmiot badań naukowych, „Kultura i Społeczeństwo” 1976, nr 4. Analiza kultury administracyjnej w Polsce oraz jej uwarunkowan historycznych: T.G. Grosse: Służba cywilna $w$ Polsce u progu XXI wieku, „Studia Polityczne” 2001, nr 12.

${ }^{17} \mathrm{~W}$ tym miejscu można również odnieść sie do kategorii instytucji totalnych, por. E. Goffman: Charakterystyka instytucji totalnych, w: W. Derczyński, A. Jasińska-Kania, J. Szacki (red.): Elementy teorii socjologicznych. Materiały do dziejów współczesnej socjologii zachodniej, Państwowe Wydawnictwo Naukowe, Warszawa 1975.

${ }^{18}$ Por. na temat kultury politycznej w Polsce: J. Staniszkis: Szanse Polski. Nasze możliwości rozwoju w obecnym świecie, rozmowa A. Zybały, Wydawnictwo Rectus, Warszawa 2005, s. 75.
} 
- Dialog służył legitymizacji autorytarnej władzy, ale nie wpływał na korektę odgórnie podejmowanych decyzji. Był więc służebny i instrumentalny wobec decyzji podejmowanych przez kierownictwo polityczne. Wiazało się to $z$ silnym propagandowym charakterem konsultacji społecznych, które - szeroko przedstawiane w mediach państwowych - miały przekonywać społeczeństwo do decyzji władz.

- „Dialog społeczny” miał charakter silnie ideologiczny i polityczny. Odwoływał się bardziej do ideologii państwa socjalistycznego, a nie do rzeczywistości społecznej i związanych $z$ nia realnych problemów. Wzmacniał podstawy ideowe ówczesnego systemu, odwołując się między innymi do doktryny nadrzędnej roli klasy robotniczej.

- „Dialog społeczny”, podobnie jak cały system władzy, był silnie scentralizowany, co oznacza, że był przede wszystkim prowadzony na szczeblu centralnym. Jeśli już był realizowany „w terenie", to pod silna kontrola centralnych organów państwa (w tym służb policyjnych). Jednocześnie silna pozycję $\mathrm{w}$ dialogu $z$ władza miały struktury branżowe, zwłaszcza najbardziej wpływowe centrale zwiazkowe. W przypadku Polski były to centrale przemysłu ciężkiego (górnictwo, hutnictwo itp.).

- „Dialog społeczny” mial charakter elitarny i oligarchiczny ${ }^{19}$. Był zawężony do grupy lojalnych wobec władzy politycznej organizacji i działaczy społecznych, którzy tworzyli nomenklaturę dawnego systemu, a więc elitarną grupe zainteresowana podtrzymywaniem ustroju socjalistycznego. Nie obejmował działaczy $z$ organizacji nieautoryzowanych przez państwo (na przykład opozycyjnych, religijnych) lub innych grup społecznych złożonych ze „zwykłych obywateli”. W przypadku Polski wyjatkiem były rozmowy prowadzone $z$ działaczami opozycyjnego zwiąku zawodowego „Solidarność” w latach 1980-1981 oraz przed zmiana ustroju (tzw. rozmowy okragłego stołu).

\footnotetext{
${ }^{19}$ Oligarchizacja organizacji społecznych jest rozumiana w odniesieniu do teorii Roberta Michelsa. Por. S.M. Lipset: Robert Michels and the "Iron Law of Oligarchy”, w: idem: Revolution and Counterrevolution: Change and Persistence in Social Structures, Basic Books, New York 1968.
} 


\section{Wpływ kultury na efektywność dialogu spolecznego}

Kultura i tradycja prowadzenia dialogu społecznego w danym kraju wpływaja w ogromnym stopniu na efektywność instytucji trójstronnych. Szczególnie niekorzystny wpływ wywiera tradycja administracyjna wywodząca się $z$ okresu państwa socjalistycznego. Jest ona związana $z$ niechęcią urzędników do konsultacji społecznych, brakiem transparentności administracji ${ }^{20}$ oraz skłonnościa do instrumentalnego traktowania organizacji społecznych - głównie jako narzędzia upowszechniającego lub wzmacniajacego poparcie społeczne dla polityki rzadu. Tendencje te sa wzmacniane przez silne upolitycznienie urzędników. Jest to zwiazane $z$ wysokim upolitycznieniem (upartyjnieniem) dialogu społecznego, co niewątpliwie utrudnia możliwości zawierania porozumień. Innym czynnikiem są silne kompleksy powiazań branżowych. Cechą wspólna sytuacji w Polsce i w Estonii jest występowanie wspomnianych powiąań sektorowych, a także silna pozycja zwiąków branżowych w dialogu społecznym. Na Litwie wpływ tych struktur jest mniejszy, co pozytywnie wpływa na efektywność dialogu trójstronnego ${ }^{21}$. Korzystnym czynnikiem dla skuteczności dialogu jest natomiast tradycja porozumień dwustronnych (między pracodawcami i pracownikami) oraz silnie rozwinięte instytucje dialogu dwustronnego.

Ważnymi przeszkodami w efektywności działania instytucji trójstronnych sa upowszechnienie kultury protestu i negacji propozycji rządowych oraz niechęć do zawierania jakiegokolwiek kompromisu. Zespół tych zjawisk określam mianem kultury dialogu negatywnego. Jest ona związana $z$ przekonaniem, że ustępstwa prowadzace do zawarcia porozumienia sa oznaka słabości lub sprzeniewierzenia wobec interesów organizacyjnych. Natomiast siła jest powiązana $z$ nieustępliwością, postawą roszczeniową i spekta-

${ }^{20}$ Szczególnie dobrze widoczne są te cechy administracji w Estonii. Por. E. Sootla, T.G. Grosse: Tripartite... .

${ }^{21}$ R. Stafejeva: Tripartite... . 
kularnym protestem społecznym, przed którym kapituluja decydenci rzadowi. Kultura dialogu negatywnego wzmacnia wzajemna rywalizacje partnerów społecznych o uznanie społeczne i członków organizacji. Upublicznienie dialogu społecznego w tych warunkach kulturowych dodatkowo ogranicza możliwości zawierania porozumień, sprzyja bowiem artykulacji odmienności stanowisk. Właśnie dlatego działacze społeczni dążą do ograniczania jawności tej metody zarządzania dialogiem.

Opisana kultura panuje na przykład w Polsce. Jest wzmacniana przez utrwalona przynajmniej od XVIII wieku tradycje protestu wobec wrogiego i obcego państwa. Warto przypomnieć, że w Polsce istnieje tradycja budowania społeczeństwa obywatelskiego nie $\mathrm{w}$ symbiozie i kooperacji $\mathrm{z}$ administracja, ale $\mathrm{w}$ opozycji do państwa ${ }^{22}$. Jest to związane $z$ bardzo niskim poziomem zaufania społecznego do instytucji demokratycznych i polityków. $Z$ badań Eurobarometru z 2005 roku wynika, że aż 84 proc. Polaków nie ma zaufania do rządu, 88 proc. nie ufa parlamentowi, a 91 proc. nie ma zaufania do partii politycznych ${ }^{23}$. Dodatkowo występuje zjawisko alienacji społecznej wobec spraw publicznych i wycofywania się do sfery prywatnej ${ }^{24}$. Rezultatami opisywanych zjawisk sa między innymi: (1) brak szacunku dla reguł państwa prawa; (2) rozwój kultury negatywnego dialogu; (3) słabość mechanizmów kontroli społecznej nad państwem i jego politykami.

Podsumowując, można stwierdzić, że kultura polityczna w Polsce sprzyja skłonności do zastępowania aktywności społecznej przez

22 J.J. Linz, A. Stepan: Problems of Democratic Transition and Consolidation. Southern Europe, South America, and Post-Communist Europe, The Johns Hopkins University Press, Baltimore - London 1996.

${ }^{23}$ Por. Eurobarometer 63. Public Opinion in the European Union, Standard Eurobarometr, European Commission, Brussels, September 2005, s. 21, 24, tabele: QA7.2, QA7.3, QA7.4. Por. też także inne badania międzynarodowe na podobny temat: Zaufanie do rzadu, przedsiębiorstw, ONZ i organizacji pozarzadowych $w 20$ krajach świata, Centrum Badania Opinii Społecznej, Warszawa, styczeń 2006; Zaufanie do instytucji publicznych w krajach Europy Środkowej $i$ Wschodniej, Centrum Badania Opinii Społecznej, Warszawa, październik 2004.

${ }^{24}$ Por. E. Wnuk-Lipiński: Społeczeństwo obywatelskie i kultura polityczna nowej Polski, maszynopis przygotowany na konferencje poświęcona stosunkom polsko-austriackim, Wiedeń Haindorf, październik 2005. 
władze publiczne. Zwiększa również prawdopodobieństwo występowania zjawisk patologicznych $\mathrm{w}$ administracji. Dotychczasowe rozważania można odnieść także do pojęcia „kapitał społeczny”, definiowanego jako zasoby określonej grupy społecznej pozwalajace na społeczną współpracę ${ }^{25}$. W przypadku Polski taka kooperacja jest podejmowana raczej przeciwko państwu i jego przedstawicielom niż we współpracy $z$ nimi. Ponadto jest to kapitał społeczny wykorzystywany raczej do opozycji wobec wysuwanych propozycji, a nie w celu budowania konsensu i porozumienia zadowalającego wszystkie strony.

\section{Szczególne znaczenie kultury politycznej}

Istotnym problemem $\mathrm{w}$ krajach naszego regionu jest silne upolitycznienie dialogu społecznego. Możemy tutaj obserwować przynajmniej dwa rodzaje zjawisk. Pierwszym jest upartyjnienie dialogu społecznego, tj. przeniesienie rywalizacji parlamentarnej i wyborczej na grunt instytucji trójstronnych. Towarzyszy temu silna afiliacja polityczna organizacji społecznych. Takie zjawisko było widoczne w pracach polskiej Komisji Trójstronnej, kiedy organizacje związkowe silnie identyfikowały się $z$ partiami rządowymi lub opozycyjnymi. Powstałe w wyniku tego konflikty uniemożliwiały prowadzenie konstruktywnych negocjacji ${ }^{26}$. Drugim zjawiskiem jest próba doraźnego i instrumentalnego wykorzystania instytucji dialogu społecznego przez ugrupowania polityczne lub członków rządu. Jako przykład tej formy upolitycznienia moga posłużyć próby wykorzystywania konsultacji społecznych do poprawienia wizerunku rządu lub polityków przed zbliżającymi się wyborami.

\footnotetext{
${ }^{25}$ Por. J.S. Coleman: Organizations and Institutions: Sociological and Economic Approaches to the Analysis of Social Structure, „The American Journal of Sociology” 1988, vol. 94 (suplement), s. S95-S120.

${ }^{26}$ Por. J. Gardawski: Między negocjacjami a dialogiem społecznym, w: P. Żuk (red.): Demokracja spektaklu?, Wydawnictwo Naukowe Scholar, Warszawa 2004. Na ten temat również: K. Frieske: Dialog społeczny: zasady, procedury i instytucje $w$ odniesieniu do podstawowych kwestii społecznych, Instytut Pracy i Spraw Socjalnych, Warszawa 1999; M. Fałkowski: Tripartite... .
} 
We wszystkich badanych krajach organizacje społeczne (zwłaszcza związki zawodowe) miały bardziej lub mniej widoczne orientacje polityczne. Nie wszędzie miało to jednak szkodliwy wpływ na dialog trójstronny. Na przykład na Litwie sympatie polityczne organizacji społecznych nie wywierały istotnego wpływu na wyniki działań Rady Trójstronnej. Ważnym czynnikiem wpływającym na funkcjonowanie tej instytucji jest kultura konsensu. W ten sposób określam skłonności do zawierania kompromisu ponad podziałami politycznymi i rywalizacją o członków między bratnimi organizacjami. Jest ona przeciwieństwem kultury dialogu negatywnego, która w warunkach silnego upolitycznienia jest szczególnie destrukcyjna dla instytucji trójstronnych. W takich warunkach częstym zjawiskiem jest niemożność wynegocjowania porozumienia lub okresowe „zawieszanie” spotkań instytucji trójstronnej. Ponadto upolitycznienie dialogu społecznego wpływa destabilizujaco na możliwość kontynuowania określonych polityk publicznych po wyborach, w tym respektowania porozumień zawartych $z$ partnerami społecznymi po zmianie ekipy rządowej.

W krajach Europy Środkowej i Wschodniej występuje silna dominacja czynnika politycznego nad dialogiem społecznym. Ilustracją tego zjawiska jest możliwość upolitycznienia dialogu społecznego nawet w sprawach, które wydają się odległe od głównego nurtu sporu politycznego. Wyrazem tej tendencji jest również skłonność działaczy społecznych do poszukiwania nieformalnego wpływu na decydentów rządowych. Na przykład w Polsce uczestniczenie $\mathrm{w}$ instytucjach trójstronnych jest okazja do nawiazywania tego typu kontaktów i wywierania wpływu na polityków. Sympatie partyjne i kontakty $\mathrm{z}$ politykami stanowią $\mathrm{w}$ tych warunkach dźwignie polityczna dla skuteczniejszej realizacji interesów danej organizacji, niejednokrotnie $z$ pominięciem dyskusji na forum instytucji trójstronnej. $Z$ kolei w Estonii dominacja logiki politycznej wstrzymała możliwości rozwoju instytucji dialogu społecznego, które są traktowane jako konkurencja dla władzy polityków ${ }^{27}$. Skutkuje to naj-

${ }^{27}$ E. Sootla, T.G. Grosse: Tripartite... . 
słabsza instytucjonalizacja dialogu społecznego wśród przebadanych krajów i niechęcią decydentów do korzystania $z$ tej metody zarzadzania przy realizowaniu polityk publicznych. We wszystkich badanych krajach stwierdzono wyższy poziom autoryzacji społecznej wyrażanej w wyborach powszechnych nad legitymizacja społeczna udzielana przez konsultacje społeczne. To właśnie dlatego wyniki konsultacji społecznych moga stosunkowo łatwo zostać przekreślone na skutek zmiany rządu po wyborach.

\section{Wpływ integracji europejskiej i transformacji ustrojowej}

Dialog społeczny na poziomie Unii Europejskiej, mimo podstaw traktatowych, cechuje stosunkowo słaba instytucjonalizacja ${ }^{28}$. Jest to instrument mało efektywny, tj. w niewielkim zakresie pomagajacy decydentom rozstrzygnać dylematy polityk publicznych między konkurencyjnymi interesami społecznymi. Dodatkowo sa to obszary spraw będace $\mathrm{w}$ zasadniczym stopniu w zakresie kompetencyjnym rządów narodowych. $\mathrm{Na}$ poziomie narodowym panuje natomiast duża różnorodność standardów dotyczących dialogu społecznego i różne formy organizacyjne tego dialogu.

Słabość unijnego dialogu społecznego powoduje, że wpływ integracji europejskiej na rozwój instytucji trójstronnych w nowych krajach członkowskich jest umiarkowany. Nie jest zwiąany $z$ obowiązkiem przyjęcia prawa wspólnotowego (acquis communautaire) $\mathrm{w}$ odniesieniu do kształtu organizacyjnego instytucji dialogu społecznego. Jednocześnie europeizacja administracji wywiera wpływ na przyjmowanie określonych zasad funkcjonowania, które można nazwać „miękkimi” metodami zarządzania (tj. nie zwiazanymi $z$ europejskim prawem i wprowadzanymi w sposób dobrowolny). $\mathrm{W}$ ten sposób integracja europejska wpływała na wprowadzanie instytucji trójstronnych i zwyczaju konsultowania polityk państwa

\footnotetext{
${ }^{28}$ Por. szerzej T.G. Grosse: Dialog społeczny w Europie, „Służba Cywilna” 2006, nr 13.
} 
z partnerami społecznymi, jako standardu obowiąujacego w Unii Europejskiej.

Jednocześnie stosowanie omawianego standardu w praktyce społecznej było bardzo niekonsekwentne. $Z$ jednej strony „miękkie” oddziaływanie integracji europejskiej sprzyjało wprowadzaniu i wzmacnianiu instytucji trójstronnych. $Z$ drugiej - częste przypadki omijania tych instytucji przez władze publiczne $\mathrm{w}$ obowiązku konsultacji odnosily się wprost do ustawodawstwa wprowadzajacego regulacje unijne ${ }^{29}$. Było to uzasadniane potrzeba pośpiesznego procedowania nad wdrożeniem dorobku prawa unijnego przed akcesją. Miało również uchronić rząd przed przedłużająca się debata społeczna, a także możliwościa zgłaszania propozycji ze strony partnerów społecznych zmieniających treść tych regulacji. Warto więc zauważyć, że asymetria negocjacji członkowskich ${ }^{30}$ między Unią Europejską a tymi krajami - której wynikiem było jednostronne dostosowanie do regulacji unijnych - utrudniała debatę społeczna $z$ dwóch głównych powodów. Po pierwsze, import unijnego prawa w zasadzie nie przewidywał możliwości dostosowania nowych instytucji do uwarunkowań społecznych nowych krajów członkowskich. Po drugie, gigantyczny rozmiar tego transferu w stosunkowo krótkim czasie $\mathrm{w}$ istocie wykluczał inicjowanie konsultacji społecznych.

Nic więc dziwnego, że implementacja tych metod w warunkach silnej tradycji socjalistycznej przyniosła słaba instytucjonalizację dialogu społecznego. Sa to niejednokrotnie instytucje wprowadzane pro forma, zmarginalizowane i mało efektywne $z$ punktu widzenia realizacji polityk publicznych. Jako przykład tego typu konsultacji

\footnotetext{
${ }^{29}$ R. Stafejeva: Tripartite....

зо Na temat asymetrii pozycji i warunków negocjacyjnych między nowymi państwami członkowskimi a Unią Europejska por. np. A. Wiener: Finality vs. Enlargement: Constitutive Practices and Opposing Rationales in the Reconstruction of Europe, w: J.H.H. Weiler, M. Wind (red.): European Constitutionalism beyond the State, Cambridge University Press, Cambridge 2003; F. Schimmelfennig, U. Sedelmeier: Theorizing EU Enlargement: Research Focus, Hypotheses, and the State of Research, „Journal of European Public Policy” 2003, vol. 9, nr 4; A. Scott: The Political Economy of Enlargement, w: F. Cameron (red.): The Future of Europe. Integration and Enlargement, Routledge, London - New York 2004; A. Moravvcsik: Preferences and Power in the European Community: A Liberal Intergovernmentalist Approach, „Journal of Common Market Studies" 1993, vol. 31, nr 4 .
} 
społecznych moga posłużyć prace nad Narodowym Planem Działań na rzecz Zatrudnienia (National Action Plan for Employment) w Estonii $^{31}$. Udział partnerów społecznych w opracowaniu tego dokumentu był minimalny. Dialog trójstronny zwiazany $z$ opiniowaniem planu traktowany był jako formalne wypełnienie europejskiego standardu, a nie przeprowadzenie autentycznej debaty społecznej. Także wpływ omawianego planu na polityke rządu jest umiarkowany, nie połączony $z$ zapewnieniem odpowiednich instrumentów administracyjnych i finansowych do jego wdrażania, monitorowania i ewaluacji. Ponadto brakuje woli politycznej do włączenia partnerów społecznych do implementacji tego planu.

Dialog społeczny podlega również specyficznym procesom wynikającym $z$ transformacji systemowej. $Z$ jednej strony dialog władzy $z$ ugrupowaniami opozycyjnymi w Polsce był istotnym mechanizmem umożliwiającym zainicjowanie transformacji. Ze względu na przejście do ustroju demokratycznego konsultacje społeczne sa wprowadzane stosunkowo szeroko, jako metoda pracy administracji publicznej. Wiąże się to nie tylko $z$ wpływem wzorców europejskich, ale także Banku Światowego ${ }^{32}$ oraz Organizacji Współpracy Gospodarczej i Rozwoju ${ }^{33}$. Z drugiej strony specyfika transformacyjna utrudnia efektywne prowadzenie dialogu. Jest to związane $z$ wielostronnościa wprowadzanych reform, sprzecznością niektórych celów reformatorów oraz szybkim tempem i potrzeba efektywnego wprowadzania zmian. Właśnie dlatego

\footnotetext{
31 Por. E. Sootla, T.G. Grosse: Tripartite...

${ }^{32}$ Wśród najważniejszych pozycji Banku Światowego dotyczących zarządzania sektorem publicznym warto wymienić: The Reform of Public Sector Management. Lessons from Experience, The World Bank, Washington DC 1991; The State in a Changing World. The World Bank, Washington DC 1997; World Development Report 1997, Oxford University Press, Oxford; Reforming Public Institutions and Strengthening Governance. A World Bank Strategy November 2000, The World Bank, Washington DC 2000.

${ }^{33}$ Por. wybrane propozycje Organizacji Współpracy Gospodarczej i Rozwoju dotyczące poprawy zarzadzania w sferze publicznej: Governance in Transition. Public Management Reforms in OECD Countries, OECD, Paris 1995; Governance in the 21st Century, OECD, Paris 2001; Preparing Public Administrations for the European Administrative Space, „Sigma Papers” 1998, nr 23, OECD, Paris (CCNM/SIGMA/PUMA(98)39); OECD/Sigma Papers nr 26 Sustainable Institutions for European Membership, OECD, Paris (CCNM/SIGMA/PUMA(98)57); „Sigma Papers”, OECD, Paris 1998, nr 27; European Principles for Public Administration, „Sigma Papers”, OECD, Paris 1999 (CCNM/SIGMA/PUMA(99)44/REV1).
} 
konsultacje społeczne w Polsce były traktowane instrumentalnie wobec nadrzędnych celów administracji państwowej i bez odpowiedniego uwzględnienia opinii partnerów społecznych ${ }^{34}$. Wspomniane trudności przypominaja ograniczenia dla dialogu związane $z$ procesami integrowania się $z$ Unią Europejska.

\section{Podsumowanie wyników badań empirycznych: od czego zależy jakość dialogu?}

Spróbujmy podsumować dotychczasowe rozważania i odpowiedzieć na podstawowe pytanie: jakie sa przyczyny słabości dialogu społecznego w krajach naszego regionu. Na początku zwróćmy uwagę na dwa zasadnicze czynniki - reformy rynkowe towarzyszące transformacji i reformy powiązane $z$ integracja europejską. Zmiana ustrojowa wymaga podejmowania szybkich, wielostronnych i bolesnych społecznie reform. Jednocześnie jest powiazana $z$ ciagiem rozlicznych reform, które liberalizuja gospodarkę i osłabiaja przywileje pracownicze, co utrudnia negocjacje społeczne, zwłaszcza aprobate takich zmian przez przedstawicieli organizacji pracowniczych. Natomiast integracja europejska pociaga za soba konieczność przyjmowania w krótkim okresie czasu rozległego zakresu prawa europejskiego, w zasadzie bez możliwości zmiany tego prawa w odniesieniu do krajowych uwarunkowań społecznych. Dlatego też $\mathrm{w}$ analizowanych krajach bardziej funkcjonalne dla zachowania spoistości systemowej oraz celów transformacji ustrojowej i integracji europejskiej jest osłabianie dialogu społecznego oraz jego instrumentalne wykorzystywanie przez polityków.

W sytuacji panujacej w nowych krajach członkowskich Unii Europejskiej instytucje dialogu społecznego sa więc słabe, a europeizacja dialogu społecznego powierzchowna. Transfer tych instytucji jest słabo dostosowany do uwarunkowań nowych krajów

${ }^{34}$ B. Gąciarz B., W. Pańków: Dialog społeczny po polsku - fikcja czy szansa?, Instytut Spraw Publicznych, Warszawa 2000, s. 32-33. 
członkowskich. W ograniczonym stopniu skupia się na praktycznej użyteczności nowych instytucji i metod zarządzania dla poprawy efektywności realizowania polityk publicznych. Warto zauważyć, że jest to związane nie tylko ze specyfika transformacji krajów Europy Środkowo-Wschodniej, ale również słabością i zróżnicowaniem wewnętrznym wzorców dotyczących dialogu społecznego płynących $z$ zachodu kontynentu. Dodatkowo widoczna była niekonsekwencja, a nawet sprzeczność zastosowania metod zarządzania transferowanych $z$ Unii Europejskiej do badanych krajów. Chodzi zwłaszcza o sprzeczność między „twardymi” metodami zarządzania, związanymi $z$ jednostronnym transferem regulacji prawnych, a wprowadzaniem „miękkich” metod zarządzania, odnoszacych się między innymi do dialogu społecznego. Import unijnego prawa w zasadzie nie przewidywał możliwości dostosowania nowych instytucji do uwarunkowań społecznych nowych krajów członkowskich, co czyniło dialog społecznym bezcelowym. Ponadto gigantyczny rozmiar tego transferu $\mathrm{w}$ stosunkowo krótkim okresie w zasadzie wykluczał inicjowanie konsultacji społecznych.

Odpowiadajac na podstawowe pytanie tego artykułu, to jest przyczyny słabej jakości dialogu społecznego w nowych krajach członkowskich, należy poza wpływem integracji europejskiej i transformacji wymienić jeszcze inne czynniki, przede wszystkim kulturę polityczną i administracyjna funkcjonującą $\mathrm{w}$ tych krajach. Odpowiada ona za wysoki poziom upolitycznienia dialogu społecznego, a także oparcie dialogu na personaliach, a nie na stabilnych i formalnych instytucjach. Mówiąc o zjawiskach kulturowych, należy również wspomnieć o syndromie cech związanych $z$ tendencja do dialogu negatywnego i kapitale społecznym wykorzystywanym głównie w celach społecznego protestu, a nie do szukania kompromisu zadowalającego wszystkie strony. Ściśle powiązana $z$ czynnikami kulturowymi jest kwestia słabości instytucji organizujących funkcjonowanie dialogu społecznego. W niektórych krajach łączy się to $z$ wprowadzaniem instytucji ograniczających możliwości szukania kompromisu. 


\section{Próba wnioskowania teoretycznego: dwa modele państwa}

$\mathrm{Na}$ podstawie dotychczasowych wniosków z badań empirycznych podejmuję próbę teoretycznej konceptualizacji zjawisk dotyczacych funkcjonowania nowych państw członkowskich Unii Europejskiej $z$ regionu Europy Środkowo-Wschodniej. Dotychczasowa analiza ujawniła, że na jakość dialogu społecznego wpływaja dwie grupy czynników. Po pierwsze, sa to czynniki zewnętrzne, tj. wzorce dotyczące zarządzania i kształtowania instytucji dialogu społecznego płynace $z$ zagranicy $w$ związu $z$ transformacją ustrojowa i procesem integracji europejskiej. Po drugie, sa to czynniki wewnętrzne, które sa związane $z$ uwarunkowaniami lokalnej kultury politycznej i administracyjnej, dotychczasowymi strukturami administracji publicznej oraz funkcjonujacymi w danym kraju instytucjami dialogu społecznego. Podstawowe pytania badawcze zmierzaja do ustalenia wzajemnych relacji między transferowanymi z zewnątrz instytucjami a uwarunkowaniami miejscowymi. Od czego zależa te relacje? Które uwarunkowania maja większy wpływ na formowanie się instytucji dialogu społecznego i sposób praktycznego wykorzystania tych instytucji do zarządzania politykami publicznymi? Czy niska efektywność i słabość instytucji dialogu społecznego wynika $z$ wzajemnych relacji między czynnikami zewnętrznymi a wewnętrznymi? Jeśli tak by było, miałoby to bezpośrednie odniesienie do teorii izomorfizmu, a więc koncepcji teoretycznych zajmujących się wpływem doświadczeń zagranicznych na kształtowanie instytucji krajowych.

Koncepcje teoretyczne dotyczące izomorfizmu ${ }^{35}$ wyróżniają dwa główne poziomy transferu instytucji: dobrowolny i siłowy (coer-

${ }_{35}$ P.J. DiMaggio, W.W. Powell: The Iron Cage Revisited: Institutional Isomorphism and Collective Rationality in Organizational Fields, w: F. Dobbin (red.): The New Economic Sociology. A Reader Princeton University Press, Princeton - Oxford 2004; M. Thatcher: Delegation to Independent Regulatory Agencies: Pressures, Functions and Contextual Mediation, „West European Politics” 2002, vol. 25, nr 1 
cive). W pierwszym przypadku możemy wyróżnić między innymi mechanizm uczenia się na doświadczeniach innych krajów. Zakłada on selektywne wprowadzanie określonych praktyk zagranicznych do krajowego systemu instytucjonalnego. Cecha opisywanego procesu jest gruntowna analiza korzyści i kosztów takiego transferu. Ponadto zapożyczenia instytucjonalne sa dokonywane pod kątem krajowych potrzeb i uwarunkowań administracyjnych. Odmiennym mechanizmem jest bezrefleksyjne naśladownictwo (mimetyzm). W tym przypadku rozwiazania zagraniczne przenoszone sa bez dokonania odpowiedniej analizy potrzeb krajowych. Głównym motywem tego procesu staje się moda intelektualna, a także chęć wprowadzenia rozwiązań, które obniżą niepewność polityczna elit krajowych lub zagranicznych w stosunku do sytuacji $\mathrm{w}$ danym kraju. Istotnym elementem wprowadzanych zapożyczeń instytucjonalnych jest więc chęć zwiększenia zewnętrznej legitymizacji dla wprowadzanych reform. Chodzi o zapewnienie zaufania dla określonych działań publicznych ze strony instytucji międzynarodowych, agencji ratingowych, inwestorów zagranicznych itp. Kolejnym procesem wymienianym w literaturze przedmiotu jest presja normatywna ze strony społeczności eksperckich i profesjonalnych (epistemic communities) ${ }^{36}$. Proponuja one wprowadzanie określonych zmian do wykonywanych zadań publicznych ze względu na doświadczenia międzynarodowe tego środowiska.

Transfer instytucji w sposób siłowy (coercive) wynika $z$ zewnętrznej presji politycznej, zależności od podmiotów zagranicznych lub przyjętych zobowiązań międzynarodowych. Ważnym sposobem takiego transferu jest integracja europejska i presja Komisji Europejskiej na wprowadzanie określonych rozwiazań instytucjonalnych ${ }^{37}$. Przyczyną występowania omawianego mechanizmu jest również siła gospodarcza niektórych państw, które moga narzucić niektóre własne rozwiazania dotyczace instytucji rynkowych innym krajom. Implementacja instytucji zewnętrznych dokonuje się pod wpływem

${ }^{36}$ P.J. DiMaggio, W.W. Powel: The Iron...

${ }_{37}$ Por. np. C. Radaelli: Policy Transfer in the European Union, „Governance” 2000, vol. 13, nr 1. 
uwarunkowań krajowych ${ }^{38}$. Zewnętrzne wzorce instytucjonalne sa niejako „filtrowane” przez krajowy kontekst kulturowy, między innymi normy i postawy urzędników, tradycję administracyjną, ustrój krajowej administracji.

Aby lepiej zrozumieć uwarunkowania lokalne dotyczace dialogu społecznego, postanowiłem zbudować dwa modele państwa ${ }^{39}$, które zostały skonstruowane zgodnie $z$ metodologia typów idealnych Maxa Webera ${ }^{40}$. Ujęcie modelowe pozwala wyodrębnić najważniejsze cechy systemowe funkcjonowania administracji państwowej i partnerów społecznych w odniesieniu do dialogu społecznego w krajach Europy Środkowo-Wschodniej. Pozwala jednocześnie na odróżnienie zespołu uwarunkowań wewnątrzkrajowych od czynników zewnętrznych, związanych $z$ transferem wzorców towarzyszących transformacji i integracji europejskiej. Przyjęta przeze mnie definicja modelu państwa odnosi się do następującego zestawu zagadnień:

- relacji administracji państwowej wobec partnerów społecznych i tak zwanego społeczeństwa obywatelskiego;

- sposobu definiowania sily państwa (state capacity) oraz zadań państwa w odniesieniu do zabezpieczenia społecznego i rozwoju gospodarczego;

- wewnętrznej racjonalności i funkcjonalności systemu administracyjnego (między innymi czy opiera się ona na hierarchicznych, czy sieciowych metodach działania);

- kultury administracyjnej (głównie w odniesieniu do transparentności administracji, gotowości do współpracy z partnerami społecznymi i mediami, zakresu upolitycznienia administracji itp.).

\footnotetext{
${ }^{38}$ Por. K.R. McNamara: Rational Fictions: Central Bank Independence and the Social Logic of Delegation, „West European Politics” 2002, vol. 25, nr 1; J.B. Goodman: The Politics of Central Bank Independence, „Comparative Politics” 2002, vol. 23, nr 3; M. Thatcher: Delegation...; K. Nakano: Cross-National Transfer of Policy Ideas: Agencification in Britain and Japan, „Governance" 2004, vol. 17, nr 2.

${ }^{39}$ Por. T.G. Grosse: New Modes of Governance in New European Union Member States. A Report on Social Dialogue in Selected European Union Countries, 2006, NewGov, Project no. CIT1-CT2004-506392, ref. No. 17/D08 (http://www.eu-newgov.org/datalists/documents.asp).

${ }^{40}$ M. Weber: Obiektywność poznania $w$ naukach społecznych, przekład M. Skwieciński, w: A. Chmielecki, S. Czerniak, J. Niżnik, S. Rainko (red.): Problemy socjologii wiedzy, Państwowe Wydawnictwo Naukowe, Warszawa 1985, s. 76-100.
} 
Punktem wyjścia do dalszej analizy jest więc rozróżnienie dwóch idealnych modeli państwa, które odnosza się do relacji między administracja państwowa a społeczeństwem obywatelskim. Pierwszym jest państwo administracyjne, drugim - państwo sieciowe. $\mathrm{W}$ pierwszym przypadku mamy do czynienia $z$ modelem państwa zredukowanego przede wszystkim do wymiaru struktur administracji państwowej bezpośrednio zaangażowanych w realizację poszczególnych działań w sferze społecznej. W drugim państwo traktowane jest jako sieć instytucji, w ramach których administracja państwowa jest jednym $z$ wielu podmiotów współuczestniczacych $\mathrm{w}$ realizacji polityk publicznych. Administracja ogranicza się do formułowania "reguł gry” i stymulowania partnerów społecznych w określonym kierunku. Polityki publiczne sa tutaj wynikiem interakcji w ramach sieci współdziałania społecznego i w dużym stopniu wynikają $z$ aktywności społeczeństwa obywatelskiego. Zaproponowana klasyfikacja odwołuje się do kategorii despotycznej lub infrastrukturalnej władzy państwowej, wprowadzonej przez Michaela Manna. Władza despotyczna oznacza arbitralna i w praktyce nieograniczoną władzę administracji nad społeczeństwem, zaś władza infrastrukturalna stwarza ramy infrastrukturalne (między innymi prawne) dla aktywności społecznej oraz wprowadza zachęty dla określonych zachowań społecznych i prowadzi dialog (negocjacje) na temat polityk publicznych ${ }^{41}$.

Oba modele zakładają odmienne rozumienie siły państwa (state capacity). Termin state capacity można zdefiniować jako zdolność (potencjał) państwa do prowadzenia polityk publicznych. Oznacza to umiejętne wykorzystywanie odpowiednich zasobów państwa i metod zarzadzania (modes of governance), które zapewniaja realizacje polityk publicznych rzadu ${ }^{42}$. Ważnym wymiarem siły państwa jest zdolność funkcjonowania $\mathrm{w}$ zmieniającym się otoczeniu

\footnotetext{
${ }^{41}$ Por. M. Mann: The Sources of Social Power. The Rise of Classes and Nation States 17601914, Cambridge University Press, Cambridge 1993.

${ }^{42}$ Por. F. Fukuyama: Budowanie państwa. Władza i ład międzynarodowy w XXI wieku, przekład J. Serwański, Dom Wydawniczy Rebis, Poznań 2005, s. 22.
} 
międzynarodowym $\mathrm{i}$ wewnętrznym ${ }^{43}$. Jest to związane $z$ zapewnieniem podstawowych funkcji państwa w odniesieniu do ustroju politycznego i gospodarczego funkcjonującego $\mathrm{w}$ danym kraju, zwłaszcza w okresie transformacji ustrojowej. Odnosi się także do zapewnienia sterowności politycznej i ekonomicznej w obliczu wyzwań związanych $z$ globalizacja i integracja europejska ${ }^{44}$.

Model państwa administracyjnego jest najczęściej powiąany $z$ wysokim zakresem kompetencji administracyjnych oraz bezpośrednim zaangażowaniem państwa w realizowanie usług publicznych. Budowanie siły takiego państwa oznacza przede wszystkim wzmacnianie struktur administracyjnych i kwalifikacji urzędników. Dla skuteczności tego modelu duże znaczenie mają techniki zarzadzania administracja (np. new public management). Model państwa sieciowego jest najczęściej powiązany $z$ mniejszym zakresem kompetencji w gestii struktur administracyjnych oraz przyjęciem roli arbitra i regulatora zachowań społecznych. Wymaga więc od administracji umiejętności kształtowania warunków regulacyjnych do odpowiedniego ukierunkowania aktywności społecznej.

Wzmacnianie potencjału państwa sieciowego nie może być ograniczone do wymiaru administracji publicznej. Powinno wzmacniać układ kooperacji między administracja oraz instytucjami społecznymi i prywatnymi, współpracującymi przy realizowaniu określonych polityk publicznych. Ważna płaszczyzna tej kooperacji sa instytucje dialogu społecznego i obywatelskiego. State capacity $\mathrm{w}$ modelu sieciowym wymaga więc silnych i autonomicznych organizacji pozarzadowych oraz efektywnych instytucji pomostowych łączacych administracje $z$ partnerami społecznymi. W sytuacji integracji europejskiej wsparcie dla krajowych organizacji społecznych powinno obejmować ich skuteczne włączanie w system współpracy międzynarodowej, zwłaszcza lobbing brukselski.

\footnotetext{
${ }^{43}$ Por. definicja state capacity w odniesieniu do zmieniających się uwarunkowań globalnych w: K.E. Brødsgaard: State Capacity in East Asia - Japan, Taiwan, China, and Vietnam, Oxford University Press, Oxford - New York 2000.

${ }^{44}$ Por. szerzej: T.G. Grosse: Principal Meanings of the Term State Capacity and Experience of Central and East European Countries, tekst przedstawiony na konferencji konsorcjum NewGov w Berlinie 10 grudnia 2005.
} 
Dla efektywności tego modelu duże znaczenie mają umiejętności i techniki współrządzenia (np. new modes of governance).

Można przyjąć, że w modelu państwa administracyjnego debata publiczna jest podporzadkowana polityce informacyjnej rza$\mathrm{du}$ i traktowana instrumentalnie $z$ punktu widzenia celów administracji. W modelu sieciowym państwo wykorzystuje proces debaty nie tylko do promocji i wzbogacania własnych pomysłów politycznych, ale także do wzmacniania partnerów społecznych, kultury dialogu i instytucji służących debacie publicznej. W modelu administracyjnym partnerów społecznych cechuje skłonność do bierności i nastawienie przede wszystkim na odbiór informacji płynacych od administracji. Wynika to $z$ wyraźnej asymetrii stron dialogu, w której dominujaca pozycje mają decydenci rządowi. W ramach tej nierównowagi zasadnicze decyzje podejmuje administracja, a partnerzy społeczni sa „przyzwyczajani” do niewielkiego wpływu na decydentów, co sprzyja ich pasywności. Ewentualna aktywność społeczna jest więc realizowana głównie poza oficjalnymi strukturami dialogu, na przykład $\mathrm{w}$ formule nieformalnych kontaktów $z$ władzą lub działań opozycyjnych. Sprzyja to tendencji do instrumentalnego wykorzystywania dialogu społecznego, patologizacji relacji między stronami dialogu lub omijania jego oficjalnych instytucji. W modelu sieciowym partnerzy dialogu aktywnie angażuja się $\mathrm{w}$ proces debaty, a później współuczestniczą $\mathrm{w}$ realizacji polityk publicznych. Jednocześnie włączenie się do programowania polityk na wczesnym etapie prac pozwala im nie tylko lepiej zabezpieczyć własne interesy, ale także skuteczniej uczestniczyć we wdrażaniu polityk publicznych.

W sytuacji słabości politycznej rząu - wynikającej na przykład $z$ braku koordynacji między polityka poszczególnych ministrów lub osłabienia zaplecza parlamentarnego rządu - potencjał państwa sieciowego może czerpać $z$ wiedzy i aktywności partnerów społecznych. Zapewnia to kontynuowanie polityk publicznych $\mathrm{w}$ strategicznych kierunkach. W przypadku osłabienia potencjału rządu w modelu administracyjnym - państwo nie ma zbyt wielkich 
możliwości wykorzystania potencjału partnerów społecznych, gdyż jest on słaby, a instytucje dialogu społecznego nie sa najczęściej autonomiczne, lecz zależne od władzy politycznej.

$\mathrm{W}$ modelu państwa administracyjnego rola przywództwa politycznego jest kluczowa dla siły państwa i zachowania sterowności nad procesami gospodarczymi i społecznymi. Osłabienie tego przywództwa nad administracją, a także zmniejszenie kontroli i umiejętności koordynowania różnych segmentów administracji przez polityków jest oznaka słabego państwa. W przypadku demokratycznego państwa administracyjnego pozycja instytucji większościowych (tj. pochodzących $z$ wyborów powszechnych) w stosunku do instytucji dialogu społecznego i obywatelskiego jest wyraźnie nadrzędna. W modelu państwa sieciowego rola polityków ogranicza się do funkcji arbitrów i mediatorów między różnymi grupami interesów. Jednocześnie ranga instytucji większościowych w systemie władzy państwa sieciowego relatywnie maleje, a wzrasta rola partnerów społecznych i instytucji nie kształtowanych poprzez akt wyborczy, w tym instytucji dialogu społecznego.

Skuteczne dostosowanie się do zmieniajacych się uwarunkowań zewnętrznych i wewnętrznych wymaga silnego przywództwa i odpowiedniego potencjału administracyjnego. Trudno jest zachować rolę arbitra i mediatora między różnymi interesami w sytuacji, gdy brak silnego przywództwa ze strony państwa skutkuje pogłębieniem kryzysu. $Z$ tego względu można założyć, że kraje transformacji ustrojowej - przynajmniej w początkowym okresie - potrzebuja zmian silnego przywództwa i tradycyjnych metod zarządzania w administracji, które są charakterystyczne dla państwa administracyjnego. Jako przykład trudności reformowania słabego państwa może posłużyć wprowadzanie nowych metod zarządzania, zwłaszcza „miękkich”, związanych z dialogiem społecznym. Można założyć, że w takiej sytuacji prawdopodobna jest niewielka skuteczność tych metod. Możliwe sa nawet przeciwne do oczekiwanych rezultaty ich wprowadzania, związane między innymi ze wzrostem zjawisk patologicznych $\mathrm{w}$ administracji. 


\section{Wnioski}

Słaba instytucjonalizacja dialogu społecznego w nowych krajach członkowskich nie jest więc przypadkowa, lecz systemowa. Nie wynika jedynie $z$ niewłaściwej lub niewystarczającej implementacji zachodnich instytucji, ale jest zwiąana $z$ dominujacym modelem państwa administracyjnego i lokalna kultura polityczna. Przeprowadzona analiza dowodzi, że efektywność dialogu społecznego (mierzona liczba zawieranych porozumień i ich wprowadzaniem w życie) jest uzależniona od trzech wzajemnie ze soba powiąanych czynników: (1) modelu państwa obowiązującego w danym kraju; (2) kultury politycznej i administracyjnej; (3) jakości rozwiązań instytucjonalnych kształtujacych dialog społeczny. Reforma dialogu społecznego w omawianych krajach musiałaby więc polegać nie tylko na poprawianiu instytucji, ale także na wprowadzeniu takich rozwiąań, które przyczyniłyby się do jednoczesnej zmiany kultury politycznej i modelu państwa.

W krajach Europy Środkowo-Wschodniej widoczna jest ciagłość instytucjonalna (path dependency ${ }^{45}$ ). Zgodnie $z$ tradycja socjalistyczna nadal dominuje model państwa administracyjnego. Zmiana tego modelu jest niezwykle trudna, gdyż opiera się on na wartościach kulturowych. Model ten wywiera wpływ na sposób implementacji do praktyki administracji państwowej nowych metod zarządzania dotyczacych dialogu społecznego. Sa one raczej adoptowane do modelu państwa administracyjnego, zamiast go przekształcać w stronę modelu sieciowego. Jest to po części związane ze specyfika okresu transformacji, która wymaga silnego przywództwa ze strony polityków i administracji, a więc preferuje dobrze znane rozwiązania modelu administracyjnego, nie zaś eksperymentowanie $z$ nowym.

\footnotetext{
${ }^{45}$ Por. definicja terminu path dependency w naukach społecznych: R.D. Putnam, R. Leonardi, R.Y. Nanetti: Making Democracy Work, Princeton University Press, Princeton 1993, s. 179-181; P. Pierson: Politics in Time. History, Institutions, and Social Analysis, Princeton University Press, Princeton - Oxford 2004, s. 17-53.
} 
Silne państwo, sprawnie posługujacce się tradycyjnymi (hierarchicznymi) metodami zarządzania, wydaje się warunkiem udanej transformacji ustrojowej. Jest to szczególnie istotne w przypadku przejścia $z$ gospodarki socjalistycznej do kapitalistycznej i udanego włączenia się w system gospodarki globalnej. Czy jednak omawiana reguła ma również zastosowanie do demokratyzacji państwa i uspołecznienia funkcjonowania administracji? Wręcz przeciwnie. Transformacja ustrojowa wymaga podejmowania szybkich, wielostronnych i bolesnych społecznie reform. Natomiast integracja europejska pociaga za sobą konieczność przyjmowania w krótkim okresie rozległego zakresu prawa europejskiego, w zasadzie bez możliwości zmiany tego prawa $\mathrm{w}$ odniesieniu do krajowych uwarunkowań społecznych. Dlatego też w analizowanych krajach bardziej funkcjonalne dla zachowania spoistości systemowej oraz celów transformacji ustrojowej i integracji europejskiej jest osłabianie dialogu społecznego, a także jego instrumentalne wykorzystywanie przez polityków.

W sytuacji panującej w nowych krajach członkowskich Unii Europejskiej instytucje dialogu społecznego sa więc słabe, a europeizacja administracji państwowej $\mathrm{w}$ odniesieniu do dialogu społecznego - powierzchowna. Transfer tych instytucji jest słabo dostosowany do uwarunkowań nowych krajów członkowskich. W ograniczonym stopniu skupia się na praktycznej użyteczności nowych instytucji i metod zarządzania dla poprawy efektywności realizowania polityk publicznych. Warto zauważyć, że jest to związane nie tylko ze specyfika transformacji krajów Europy Środkowo-Wschodniej, ale także ze słabością i zróżnicowaniem wewnętrznym wzorców dialogu społecznego płynacych z zachodu kontynentu. Dodatkowo widoczna była niekonsekwencja, a nawet sprzeczność zastosowania metod zarządzania przenoszonych $z$ Unii Europejskiej do badanych krajów. Chodzi zwłaszcza o sprzeczność między "twardymi” metodami zarządzania, związanymi $z$ jednostronnym transferem regulacji prawnych, a wprowadzaniem „miękkich” metod zarządzania, odnoszących się między innymi do dialogu 
społecznego. Import unijnego prawa $\mathrm{w}$ zasadzie nie przewidywał możliwości dostosowania nowych instytucji do uwarunkowań społecznych nowych krajów członkowskich, co czyniło dialog społeczny bezcelowym. Ponadto gigantyczny rozmiar tego transferu $\mathrm{w}$ stosunkowo krótkim czasie $\mathrm{w}$ istocie wykluczał inicjowanie konsultacji społecznych.

Słabość instytucjonalizacji dialogu w badanych krajach wyraża się między innymi zależnością omawianych instytucji od czynników politycznych i personalnych oraz wpływowych interesów. Sa one związane między innymi $z$ kompleksami powiązań branżowych. Niezgodność nowych metod zarządzania dialogiem społecznym $z$ obowiąujacym modelem państwa i kultura polityczna powoduje więc, że metody te sa nieefektywne w działaniu i niejednokrotnie realizowane $\mathrm{w}$ sposób daleki od celów. W niektórych sytuacjach moga być wykorzystywane instrumentalnie. Moga także utrwalać patologie organizacyjne słabego państwa oraz przyczynić się do jego dalszego osłabienia. Jest to również powiązane $z$ mechanizmem błędnego koła osłabiania instytucji dialogu społecznego. Zamiast poszukiwania rozwiązan korygujacych i wzmacniających te instytucje decydenci staraja się je omijać, poszukuja porozumienia $z$ partnerami społecznymi poza instytucjami trójstronnymi lub kreuja inne, bardziej im odpowiadajace areny dialogu.

Podstawowa rola dialogu społecznego $\mathrm{w}$ tych warunkach jest funkcja legitymizacyjna. W mniejszym stopniu odnosi się ona jednak do zwiększania akceptacji społecznej dla trudnych zmian systemowych lub polityk publicznych, a bardziej do rekompensowania słabości podmiotów uczestniczacych w dialogu. Jest to związane $z$ podwyższeniem autorytetu społecznego partnerów społecznych i przedstawicieli administracji, w tym również polityków przygotowujących się do rywalizacji wyborczej. Istotnym aspektem legitymizacyjnej funkcji dialogu społecznego jest także uzyskanie legitymizacji zewnętrznej, a więc na forum międzynarodowym. Chodziło przede wszystkim o uzyskanie akceptacji ze strony Komisji Europejskiej i rządów „starych” krajów członkowskich Unii. 
Podsumujmy dotychczasowe wnioski $z$ punktu widzenia teorii izomorfizmu. Chodzi o ustalenie wzajemnych relacji między czynnikami zewnętrznymi i uwarunkowaniami wewnątrzkrajowymi oraz ich wpływu na kształtowanie instytucji i efektywność dialogu społecznego w nowych krajach członkowskich Unii Europejskiej. Jak wykazały badania, wpływ czynników zewnętrznych był stosunkowo słaby. Wzorce płynące $z$ Unii i „starych” krajów członkowskich były rozbieżne i rozproszone. Jednocześnie sposób transferu tych wzorców był „miękki”, tj. pozostawiajacy poszczególnym krajom daleko idący zakres uznaniowości w wyborze i zakresie ich implementacji. Na przykładzie integracji europejskiej widoczna była również sprzeczność między „miękkimi” unijnymi wzorcami dotyczącymi dialogu społecznego a rzeczywistościa asymetrycznej integracji oraz „twardym” (siłowym) transferem prawa europejskiego.

Rola czynników wewnętrznych w kształtowaniu instytucji dialogu społecznego i praktyki wykorzystania tych instytucji przez decydentów politycznych okazała się natomiast wyjątkowo silna. Mieliśmy więc do czynienia $z$ konfrontacja „miękkiego”, wewnętrznie zróżnicowanego i sprzecznego transferu zewnętrznego $z$ silnie ukształtowanym zespołem cech państwa administracyjnego. Choć instytucje zewnętrzne były implementowane w sposób bezrefleksyjny i mimetyczny, podlegały jednak silnym wpływom uwarunkowań krajowych. Były więc spontanicznie „filtrowane” przez cechy państwa administracyjnego oraz tradycje administracyjna wywodzaca się $z$ okresu realnego socjalizmu. W rezultacie wzorce zagraniczne były adaptowane do uwarunkowań państwa administracyjnego i wykorzystywane zgodnie $z$ logiką działania administracji publicznej tego modelu państwa. Konsekwencja niedopasowania transferowanych instytucji zewnętrznych oraz uwarunkowań wewnętrznych jest więc: (1) powierzchowność i słabość instytucjonalizacji dialogu społecznego; (2) nieprzydatność dialogu dla skutecznego realizowania polityk publicznych (reform) oraz (3) instrumentalne wykorzystywanie dialogu przez głównych aktorów w celu zwiększenia legitymizacji wewnattrzkrajowej i zagranicznej. 